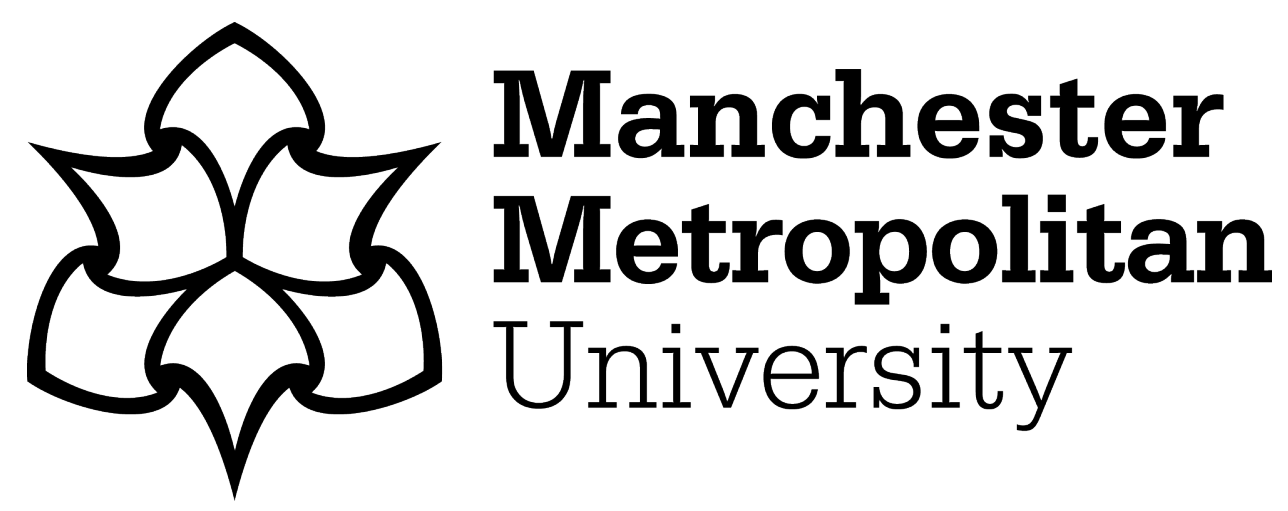

Berry, CP (2017) ' $D$ is for dangerous': devolution and the ongoing decline of manufacturing in Northern England. In: Developing England's north: the political economy of the Northern Powerhouse. Building a Sustainable Political Economy: SPERI Research \& Policy . Palgrave Macmillan, pp. 85-119. ISBN 3319625608

Downloaded from: https://e-space.mmu.ac.uk/620774/

Publisher: Palgrave Macmillan

Please cite the published version 


\section{' $D$ is for Dangerous': devolution and the ongoing decline of manufacturing in Northern England}

\section{Craig Berry}

The notion that Northern England represents - or may represent - a 'powerhouse' within the British economy clearly connotes the North's industrial past, as well as intimating an industrial renaissance in the not-too-distant future. But now for the bad news: connotations and intimations are probably as good as it is going to get. There would appear to be very few reasons to believe that the Northern Powerhouse agenda, as promulgated by then Chancellor of the Exchequer George Osborne, foretold the kind of radical shift in economic statecraft that would in all likelihood be required to transform the prospects for manufacturing industries in the North (and indeed elsewhere in the UK). This is despite the clear resonance between the possibility of a manufacturing resurgence and the wider economic 'rebalancing' agenda, which new Conservative Prime Minister Theresa May appears to have revived despite initially distancing her government from the Northern Powerhouse moniker. Most obviously, 'imbalances' between Northern and Southern England, and manufacturing and financial services industries, are identified as key dimensions of the UK's economic malaise. The discourse around rebalancing has also repeatedly cited imbalances between exports and imports, and investment and consumption - both of which imply that manufacturing (and therefore the North, at least to some extent) will be more important to the UK's economic future than it has been to the recent past. Devolution - to Northern city-regions, although not exclusively so - has been presented as part of the solution to these problems. Yet it seems the content of the devolution 'deals' agreed between central and local government since 2010 (as well as the ways in which the Conservatives have paradoxically sought to strengthen central government) reinforces industrial policy traditions which have served to marginalise manufacturing within the UK political economy.

This chapter considers recent policy practice in these areas - emanating from both the Conservative/Liberal Democrat coalition government of 2010-2015 and the Conservative majority government of 2015 onwards - in historical context, in terms of both industrial policy traditions and trends in manufacturing performance in the UK. It is organised around 'the three Ds' of manufacturing decline in Northern England. The chapter looks first at deindustrialisation and its implications for economic activity in the North, including the more recent consequences of the financial crisis and 'Brexit', that is, the UK's withdrawal from the European Union (EU). It then looks more closely at the devolution agenda as a dimension of industrial policy and economic statecraft more generally. Finally, the chapter reflects on the notion of economic development in relation to manufacturing in Northern England, advancing a specific argument about the de-development of the Northern economy (which has been reinforced by Brexit). The third section therefore seeks to situate what is happening in and to the North within a broader understanding of capitalism and uneven development, suggesting that Northern England is largely absent from a refurbished global capitalist 'core', and instead largely resides in the periphery or semi-periphery of the global economic order. The North's more peripheral status may in fact create new opportunities for growth, but on subservient terms, and accompanied by greater inequality within the North. 


\section{Deindustrialisation and the North/South divide}

\section{Manufacturing and economic decline}

By any measure, the UK's manufacturing sector has been experiencing a long-run decline. Arguably, decline has been relative rather than absolute, insofar as manufacturing output continued to grow in the UK even as it grew (much) faster elsewhere, particularly in Germany, Japan and the United States from the mid-late nineteenth century to the early-mid twentieth century. However, it is clear that from at least the Second World War onwards, manufacturing output growth has noticeably slowed in the UK. This began to translate from the 1970s onwards into enormous job losses, especially under the Margaret Thatcher and Tony Blair governments, as the UK economy in general dipped several times into recession, and manufacturing industries in particular began to face competition from non-OECD countries (Froud et al, 2011; Matthews, 2007). There has of course been no single moment of crisis within UK manufacturing throughout this period, and generally speaking the value of manufacturing output has remained constant in recent decades even as manufacturing employment has plummeted, and the share of manufacturing within the UK's overall economic output has shrunk (PricewaterhouseCoopers, 2014). This may help to explain why UK policy elites have been relatively indifferent to manufacturing decline - yet their complacency is misplaced.

That said, manufacturing does feature, albeit sometimes only implicitly, in some of the main 'declinist' accounts that have been uphold by UK elites at various times, which focus primarily on how the UK's economic decline in relative terms had reduced its influence on world affairs in absolute terms. In these accounts, decline is said to be a product of the failure of the UK's 'gentlemanly' economic culture (and/or the absence of a bourgeois revolution) to instil an entrepreneurial flair among nouveau-riche industrialists, or of how the success of the UK's industrial revolution - propelled by the access to natural resources and consumer markets enabled by British imperialism, as well as technological ingenuity - led to complacency among elites regarding the construction of a continental-style developmental state (English \& Kenny, 2000; Gamble, 2000). It was, however, the more critically-focused decline theorists, however, who focused most directly on the ailments of manufacturing in the UK, with scholars such as Geoffrey Ingham and Karel Williams identifying the nature and role (and political power) of the finance sector in both starving the manufacturing sector of capital, but also, crucially, instilling among manufacturers a short-termist business model that made industry unusually vulnerable to overseas competition (Ingham, 1984; Williams et al, 1983).

However, the 1970s 'stagflation' crisis undermined the notion of an activist, manufacturing-centred industrial policy, even if it had never really been tried in the UK (as discussed further below). The most influential decline account, offered by W.D. Rubinstein (1993) - one to which Margaret Thatcher adhered - identified the same circumstances as Ingham and Williams, but reached the opposite conclusions. The finance sector, in this account, was not holding UK industry back; rather, the finance sector is UK industry, and should be protected and promoted as the UK's key industrial speciality. This is one of the reasons that the Thatcher government sought to maintain a high value of sterling: making the City of London more attractive, but manufacturing exports less attractive. There is of course little doubt that declinism abated in the 1990s as a finance-led growth model appeared to be responsible for delivering sustained economic growth (and tax revenues which enabled high levels of public sector investment under the Blair government). The development of the European single market probably helped in this regard, in terms of providing consumers for 
financial services exports, and indeed in helping to sustain (but not necessarily revive) some manufacturing industries.

The 2008 crisis problematised this model, and led to greater elite-level attention on some of the problems that tend to mount when ostensibly highly developed economies see their manufacturing base shrink. Firstly, insofar as a smaller manufacturing base made the UK more dependent on finance, the country was seemingly afflicted by 'the finance curse' whereby productive activity is handicapped by financial rent extraction, and the growth path mirrors the inherent volatility of the finance sector (Christensen et al, 2016). Secondly, the UK's current account balance deteriorated significantly during this period, reaching a deficit of around $£ 15$ billion ( 3.5 per cent of GDP) by 2008 with a trade deficit of around $£ 13$ billion, resulting from a decline in manufacturing exports, the main culprit (Office for National Statistics, 2016a; see also Rowthorn \& Coutts, 2013). Thirdly, manufacturing's demise is the central explanation for the UK's productivity problem, insofar as manufacturing is at root the application of technology to natural resources, and therefore the motor of innovation within capitalist economies (irrespective of how the manufacturing sector is categorised statistically) (Chang, 2014: 256-267).

\section{The economic geography of deindustrialisation}

Manufacturing decline clearly has an impact on the UK economy at the aggregate level. Yet its impact has not been felt evenly across the country. The concentration of manufacturing in Northern England is perhaps the most important explanation for elite indifference to manufacturing decline - which might be characterised more cynically therefore as complicity rather than, as suggested above, merely complacency. Although manufacturing output has traditionally been fairly even spread across UK regions since the 1970s, the sector has clearly been a more important part of some regional economies than others. As late as 1997, manufacturing represented around 25 per cent of regional GVA for the North East, 24 per cent for the North West, and 24 per cent for Yorkshire and Humberside. The proportion was comparable in Wales, slightly higher for the Midlands regions, but significantly lower for Southern regions (only 7 per cent in London) and Scotland. A similar pattern is evident for 2014 (the latest available data), although the gap between the Northern regions (the share of manufacturing is 15-16 per cent in all three regions) and the East and the South West has narrowed, while grown significantly larger between the Northern regions and London and the South East (Office for National Statistics, 2015).

An important caveat to the notion of manufacturing decline is that it is not unique to the UK. Deindustrialisation, which Andy Pike defines as 'the contraction and rationalisation of manufacturing industry' (Pike, 2009: 51), is a process common to the vast majority of advanced capitalist economies, and indeed is often seen as a hallmark of development rather than an economic problem or dilemma. However, as suggested above, it has certainly been steeper in the UK than most, or indeed all, comparable countries (Rowthorn \& Coutts, 2013). Moreover, it is important to be clear about the precise implications of deindustrialisation; crucially, it acquires most meaning in relation to particular local economies, invariably described as 'deindustrialised regions'. Deindustrialisation typically refers to declining manufacturing employment; this usually accompanies a lower share of manufacturing within overall output, but not necessarily. It certainly does not mean that manufacturing output declines in absolute terms, as the process is generally characterised by a shift towards highervalue, capital-intense manufacturing industries, with lower-value, labour-intense industries migrating to 'newly industrialising countries' as part of the proliferation of transnational production networks. 
As such, it is from the UK's apparent embrace of a 'post-industrial' economy, largely eschewing the opportunity to move towards higher-value manufacturing in place of mass industry, that deindustrialisation acquires most meaning in the UK context. While some Northern cities have, eventually, developed economies that might broadly be conceived as post-industrial - obviously, services sector employment has grown in all parts of the UK in both relative and absolute terms - many places remain scarred by the loss of manufacturing (Hudson, 2013). Employment rates and earnings have invariably been significantly lower in the Northern regions (and, generally speaking, the Midlands) than in the South as a result (although it is worth noting that earnings in London and the South East have surged ahead of the rest of the South in the last 10-15 years) (Office for National Statistics, 2016c). While the picture is inevitably complex, geographers such as Danny Dorling (2010) have argued persistently and persuasively that the so-called North/South divide in England is therefore widening rather than narrowing, as embodied in differing outcomes for deprivation and life expectancy, as well as the labour market, across the divide. Interestingly, Dorling has of course always included the Midlands within the divide, rather than conveniently leaving these regions out of the overly parsimonious North/South framework. He generally argues that a jagged, diagonal line from Gloucester in the West to Grimsby in the East marks the border between North and South in England, in terms of understanding geographical inequalities.

There are of course Northern cities which buck these trends - York, for instance, consistently scores highly on the measures deployed by Dorling and others (it is of course not a coincidence that York's economy was never as heavily industrialised as most other local economies in the North). Furthermore, Manchester is often lauded as a post-industrial success story, but perhaps serves as an ideal reminder that the apparent success of some Northern cities in adapting to the services economy has not eradicated problems associated with deprivation. The City of Manchester is among the local authority areas with the highest deprivation problem, with 40 per cent of its wards in the most deprived decile of wards across England (Bullen, 2015). The volume City of Revolution, edited by Jamie Peck and Kevin Ward, on the post-industrial 'restructuring' of Greater Manchester offers an illuminating account in this regard. Peter Dicken (2002) charts Manchester's transition 'from globaliser to globalised', noting its subservient role in global production networks that it once sat at the apex of, and the coalescence of prosperity and vulnerability. Benito Giordano and Laura Twomey (2002) identify an 'intractable' joblessness result as one of the consequences, as the 'hype' around post-industrial growth is challenged through evidence of the ephemerality of high-value services industries in Manchester since the 1970s, and Dean Herd and Terry Patterson (2002) note the failure of recent welfare-to-work programmes to address the structural sources of such problems. Rosemary Mellor charts the development of Manchester's city centre, noting 'the scale of the poverty-belt enveloping the urban playground' (2002: 217). Manchester's poor are both more dependent on the city centre as inner city neighbourhoods decay, and more excluded from it. Nevertheless, more recent work by Ward, with others, demonstrates the extent to which Manchester is seen as an exemplar of city-regional governance - and indeed the extent to which its own leaders have carefully cultivated this 'mythic' image (Haughton et al, 2016; see also the chapter by Blakeley and Evans in this volume).

This story is not - or is no longer - unique to Manchester, as the contradictory dynamics of post-industrialism have been evident in many parts of the North to a greater or lesser extent, and indeed other parts of the UK. Many parts of Southern England, especially parts of the Greater London area, were also of course dependent on manufacturing, even if the regional economy was overall more diverse. Yet these economies have been more able to build upon their diversity to grow financial services and other knowledge-intense service industries, and indeed retain and grow some high-value manufacturing industries such as 
pharmaceuticals and computing which are heavily intertwined with higher education institutions in the South East, in part due to their proximity to London (Elledge, 2016; Pike, 2009: 54). Peck's work, with Nik Theodore, on 'variegated capitalism' provides an important step towards understanding such dynamics. For Peck and Theodore (2007), the process of capitalist restructuring - essentially, the opening of new sites of globally chained production as the West deindustrialises - is both spatially bound, emerging from and relying upon specific economic geographies (such as the City of London's global role) and exhibits common underlying logics, as large cities within the West develop new relationships with each other and the industrialising semi-periphery.

We can perhaps think of such shifts as emblematic of the regrouping of the core within the global capitalist economy, a process known more innocently as 'globalisation', whereby cities demonstrating leadership in knowledge-intense industries become increasingly interconnected (with connections spreading into elite cities within the so-called developing world) while becoming partially detached from their domestic political and economic environment. Yet we must not forget that post-industrialism is a British story as well as a global story. Variegated capitalism may have served as a useful rejoinder to the methodological nationalism inherent in Peter Hall and David Soskice's (2001) 'varieties of capitalism' thesis, but the condition of Northern England is evidently a product of a very British variety of deindustrialisation (see Pike, 2009). The need to eschew methodological nationalism need not simultaneously require us to overlook the abiding force of industrial practices reinforced by national-level institutions. The varieties of capitalism literature is also useful (as Peck and Theodore acknowledge) insofar it emphasises the role of institutional and evolutionary dynamics in explaining political-economic outcomes - an analytical approach embraced by Ray Hudson (2005), for instance, in accounting for the particularities of Northern demise.

\section{The impact of the 2008 crisis}

It would be incorrect to presume that 2008 represented a significant rupture within the manufacturing sector in the UK, as it did for the rest of the economy - because manufacturing had not shared in the pre-crisis boom. Unlike other sectors, there had been no upturn in manufacturing output between 2002 and 2007, and stagnation in manufacturing pay helped to hold back general earnings growth even as the economy soared (Berry, 2015a; Froud et al., 2011). The impact of the recession on manufacturing output was of course significant: output in manufacturing remains more than 6 per cent below its pre-crisis peak in 2007, and around half a million jobs have been lost in the sector (Office for National Statistics, 2016b). This helps to explain how output per head has fallen across the Northern regions since 2008, while rising elsewhere, particularly London and the South East (Berry and Hay, 2016, pp. 4-5). Interestingly, however, job losses in manufacturing have been comparable to those in other regions. The North East, North West and Yorkshire and Humberside have experienced, respectively, a 13 per cent, 11 per cent and 6 per cent decline in manufacturing employment since their pre-crisis peaks, yet these figures are lower than a decline of 18 per cent in London, 19 per cent in the South East, and comparable to the East of England (12 per cent), the South West (10 per cent), East Midlands (10 per cent) and West Midlands (8 per cent) (Office for National Statistics, 2016d).

As such, we can perhaps conclude that the 2008 crisis has not had a disproportionate impact on manufacturing in the North in any direct sense, notwithstanding the greater reliance of Northern regions on manufacturing employment. The issue is more one of the North's ability to adapt to such shocks, and whether greater barriers to developing a genuinely post-industrial economy in the North means its development will be held back by 
the non-reversal of manufacturing decline. It seems likely, however, that Brexit will have a more direct, targeted impact on manufacturing in the North, insofar as exporting manufactured goods to Europe (as opposed to selling to the rest of the world, or to domestic customers) is more central to the business model of manufacturers in the North (Berry et al, 2016). Moreover, the products of the industries to which the EU imposes the highest tariffs generally speaking, cars and chemicals - are significantly more likely to be located in the North and the Midlands, particularly the North East. Conventional wisdom suggests that the enormous fall in the value of sterling that immediately followed the Brexit vote should have boosted manufacturing exports, but UK manufacturing is now heavily dependent on the import of components due to 'broken' domestic supply chains (Pike et al, 2012: 32-34) something which particularly muddies the ostensible post-crisis success story of car manufacturing in the North East, which is reliant on both finance and components from Japan (Berry, 2015a: 183). Crucially, even if the UK were to negotiate entry into the European Economic Area along the lines of Norway - which at the time of writing is far from certain it would not be part of the EU's customs union, meaning that 'rules of origin' provisions would apply. Goods that the UK exports to the EU would have to be substantially composed of content produced domestically, or indeed within the EU itself, to qualify for tariff-free single market access (Piris, 2016: 8).

\section{Devolution and the Northern Powerhouse in the British industrial policy tradition}

\section{Industrial policy in the UK}

Any exploration of manufacturing decline requires an understanding of the UK's industrial policy tradition, not least because the line between industrial and regional policy in the UK has always been a blurry one. By conflating a desired industrial renaissance with an agenda around local government reform, the Northern Powerhouse agenda arguably served to intensify this inheritance. Industrial policy involves the state deliberately favouring manufacturing industries over others, irrespective of market signals. Essentially, through industrial policy the state intervenes 'vertically' in parts of the economy in order to ensure that private economic actors are properly incentivised to pursue the public good of enhanced productivity (for the benefit of the entire economy). This definition is of course a contested one - and the contest has a direct bearing upon the British industrial policy tradition. UK policy-makers would generally claim that Britain has long upheld a functional industrial policy regime, albeit one that operates 'horizontally' to improve the general environment for all business activity, rather than vertically in support of manufacturing and related industries. This chapter is based on the assumption that industrial policy, by definition, has to be vertical in nature. Yet this debate is of little consequence for our present purposes. It is more important to note that manufacturing benefits most, by design, from vertical industrial policy. That the UK favours a horizontal approach signals the British state's longstanding indifference to manufacturing (and by extension, the regions most reliant on manufacturing industries) (Berry, 2017).

As such, direct support for manufacturers has generally taken the form of 'soft' interventions such as advice services and the dissemination of best practice and tax allowances for R\&D or capital investment (Buigues and Sekkat, 2009). It should be noted that in the 1970s, Harold Wilson's Labour government introduced a more interventionist approach, involving direct subsidies and planning agreements, although the agenda became largely focused on defensive interventions to rescue unproductive firms and industries (Coates, 2015). The 2008 crisis, however, appeared to reignite an interest among policy elites in industrial policy, and indeed seemed to endorse vertical interventions in support of 
manufacturing, insofar as the Conservative-Liberal Democrat coalition promised to 'rebalance' the economy from finance (or services in general) towards manufacturing, and from London and the South East (or the South in general) towards the North. This narrative had already been present to some extent in the Labour government's post-2008 agenda - as represented in the New Industry, New Jobs (HM Government, 2009) strategy - but it was only from 2010 onwards that more explicit references to the geographical dimension of supporting manufacturing through industrial policy firmly re-entered the lexicon of the UK policy elite. The 2010 coalition agreement stated that:

We want to create a fairer and more balanced economy, where we are not so dependent on a narrow range of economic sectors, and where new businesses and economic opportunities are more evenly shared between regions and industries (HM Government, 2010: 9).

An accompanying speech by new Prime Minister, David Cameron (2010) argued that 'our economy has become more and more unbalanced, with our fortunes hitched to a few industries in one corner of the country, while we let other sectors like manufacturing slide', and in 2011 the coalition's 'plan for growth' repeated:

Sustainable growth requires a rebalancing of the UK economy away from a reliance on a narrow range of sectors and regions, to one built on investment and exports, with strong growth more fairly shared across the UK (HM Treasury and Department for Business, Innovation and Skills, 2011: 28).

The 'plan for growth' was of course launched by George Osborne's now infamous 'march of the makers' speech (Osborne, 2011). But what kind of policies were actually associated with this agenda? Access to finance - primarily a horizontal issue, focused on small and mediumsized enterprises (SMEs) in general rather than any particular industry - has been a core concern. The government has issued loan guarantees that could amount to around $£ 2$ billion, in addition to the Bank of England's Funding for Lending scheme, although this scheme was initially used predominantly to support mortgage lending. The British Business Bank enabled a more direct form of lending to SMEs, albeit with funds of only around $£ 1.5$ billion. Other measures focused on SMEs include better targeting of government procurement, increased apprenticeship funding, and tax and planning incentives within 'enterprise zones'. There were more vertical forms of support for manufacturing industries. Perhaps what is most interesting, however, is that policy-makers (especially elected politicians) were content to create the impression that industrial policy was being targeted on particular, strategically significant industries; for example, in the coalition's 2012 industrial strategy, outlining the eleven key sectors as the focus of government action (many of which were manufacturing and related industries) (HM Government 2014). Yet arguments in 'the plan for growth' that might support a more interventionist industrial policy run alongside support for fiscal conservatism, lower taxes and deregulation, and flexible labour markets (albeit with a higher-skilled workforce). This might help to explain the conservatism of the government's agenda in this regard. The creation of a series of 'catapult centres' related to particular sectors or industries was probably the most significant policy, although the centres were not all entirely new. The centres enable firms and universities to collaborate on R\&D and access common, publiclyfunded resources (they are expected to become profitable and attract private funding in the medium-term). The Advanced Manufacturing Supply Chain Initiative (at a cost of around $£ 240$ million) is also worth noting, as is the coalition's extension of tax allowances related to capital investment, which primarily benefit manufacturers. 
Vince Cable, Liberal Democrat MP and Business Secretary within the coalition government, clearly wanted to have gone further, especially in terms of advanced manufacturing. He openly criticised the government's 'piecemeal' approach to industrial policy, and argued that greater state intervention was legitimate and necessary, because public investment was more efficient than private investment from the perspective of boosting productive capacity over the long term (Cable, 2011; 2012). He enjoyed support from both the Confederation of British Industry and the Trades Union Congress for his position, as well as his departmental colleague, science minister and Conservative MP, David Willets (see Willets, 2012). But we must not exaggerate Cable's radicalism in this regard. Indeed, in 'sector analysis' published by his department in 2012, it was stressed that '[h] $\mathrm{h}$ orizontal policies, such as setting the legal and regulatory frameworks in which businesses across the economy operate, form the bedrock of industrial strategy'. The momentum behind the coalition's industrial strategy appeared to have waned significantly by 2015, before disappearing in all but name following the Conservative Party's 2015 general election victory (Berry, 2017). Intriguingly, during Theresa May's campaign for the Conservative Party leadership, after the Brexit vote, she signalled her support for a 'proper industrial strategy' and 'economic reform', echoing remarks from 2013 in favour of 'a more strategic role for the state in our economy' (May, 2013; 2016c). However, there are as yet few genuine signs that she intends to transform UK industrial policy (Berry, 2017).

Furthermore, insofar as May's words can be taken at face value, she appears less keen than her former colleagues in the Conservative Party to explicitly associate industrial strategy with support for either manufacturing or Northern England.

\section{Regional policy and the emergence of the Northern Powerhouse}

In recent decades, regional policy has in the UK effectively functioned as industrial policy by proxy - and it was at the regional level that the state apparatus appeared during this period to take on a more interventionist or vertical pose. This applied most to the New Labour era, with the Blair government clearly more inclined to take an interest in its depressed 'heartland' constitutions in the North, but it was also, to a lesser extent, a feature of the Thatcher and especially Major governments' agenda. This was again often limited, however, to defensive moves, in recognition of the particular economic geography of hardships associated with deindustrialisation. In general, the regional layer simply replicated the horizontal approach of national government, and indeed probably reinforced it, by encouraging all regions to pursue similar economic objectives, often in competition with each other and paradoxically with little sense that strategies were genuinely 'place-based' (Bailey \& Driffield, 2007; Bailey et $a l, 2015)$. As suggested above, one of the interesting paradoxes of post-crisis industrial policy in the UK is that those most in favour of a more vertical approach at the national level seem least concerned about the geographical dimension to supporting manufacturing. Vince Cable, for instance, appears not to have bought into Northern Powerhouse to any extent, despite the fact that his party leader, then Deputy Prime Minister Nick Clegg, arguably initiated the coalition's interest in this area, albeit in a rather nebulous manner through his Northern Futures initiative. Incredibly, among Cable's flagship catapult centres, only two of eleven current centres have a Northern footprint: the medicines discovery centre is based in Cheshire, and the high-value manufacturing centre has seven bases, one of which is in Redcar, with a further two in Rotherham (connected to the University of Sheffield).

Shortly before becoming Prime Minister, Theresa May appeared to signal that her government would not champion the North above other areas, arguing that she would initiate 'a plan to help not one or even two of our great regional cities, but every single one of them' (May, 2016c). This implied rebuke to Osborne's focus on the North has subsequently 
softened, although it is probably significant that she first resuscitated the Northern Powerhouse moniker when speaking directly to a Northern audience, writing in The Yorkshire Post that 'Yorkshire is a key part of our vision for a Northern Powerhouse - our plan to help the great cities and towns of the North pool their strengths and take on the world' (May, 2016a). The Northern Powerhouse is perhaps understood by May as a policy agenda (or branding) relevant to the North, but not necessarily the UK economy in general. Comically, a similar article endorsing 'the Midlands Engine' (a later Osborne concoction) appeared in The Birmingham Mail on the same day (May, 2016b). Ultimately, of course, the fact that politicians such as George Osborne (who represents a constituency in Cheshire) were keen to promulgate the idea of a Northern manufacturing revival does not mean they upheld a more genuinely place-based approach to industrial policy than espoused now by Theresa May. The memoirs of former Liberal Democrat minister David Laws revealed that, after Clegg lobbied Osborne to include Sheffield (where Clegg's constituency is) rather than Leeds in the first wave of announcements related to the Northern Powerhouse, Clegg told him that 'George is hilarious. He immediately suggested including Sheffield and just dropping Leeds' (cited in Chakrabortty, 2016).

The coalition government's interest in local growth started somewhat inauspiciously when it abolished Labour's Regional Development Agencies (RDAs) immediately after coming to office. RDAs were New Labour's attempt to revolutionise the governance of local economic development in England, using central government budgets more effectively to support new and growing industries, not least to enable post-industrial transition and engender more balanced growth. While Scotland and Wales began the path to political and constitutional devolution in Labour's first term, RDAs were explicitly designed as arms-length, apolitical bodies (the Labour government quickly aborted half-hearted efforts democratise regional policy in England during its second term following a referendum defeat in the North East). Defined by their regional location rather than any particular vision for industrial policy, there were few natural limits to the scope of their responsibilities. The resources, of course, seldom matched the policy ambition. While many RDAs lobbied for further devolution, for others it was rather unwelcome. Transplanted on top of a historically messy governance hierarchy in England, RDAs ultimately became a new institutional repository for the mess (although this does not mean they were entirely unsuccessful, judged on their own terms). Although RDAs were pitched by Labour as the solution to the malaise of deindustrialisation, they were largely place-blind in practice, arguably more so than the minimal regional economic development structures created by the Conservatives in the 1980s and early 1990s (although they were less explicitly market-oriented). Every part of England was covered by an RDA, including London, in contrast to the European norm of focusing regional policy initiatives on the areas most in need (Pike et al, 2016a; Pike \& Tomaney, 2009).

RDAs were replaced by Local Enterprise Partnerships (LEPs), semi-autonomous bodies, organised loosely on a city-regional basis, led by representatives of both local government and local business communities working in partnership. It is worth noting that RDAs had themselves become more local or city-based over time, particularly during Labour's third term when they were instructed to deliver interventions via local authorities as far as possible, and (unelected) regional supervisory chambers were abolished (Pike et al, 2016). LEPs were established by central government, but were given miniscule resources to fund a small core staff and organisational administration. LEPs do not themselves invest, but are expected to encourage investment by public and private actors in self-defined priority areas. LEPs hold few, if any, actual policy powers. While conceived as an attempt to instil a genuinely (business-defined) localism, LEPs' lack of power and resources is compounded by the problem of multiple and blurred lines of accountability (enabling reinvented forms of 
centralisation), gerrymandered and overlapping political boundaries, and a constitutive inability to address market failure (Jones, 2013; Pike et al, 2015).

The non-statutory and unincorporated nature of LEPs means the initiative has functioned in parallel with, but only loosely connected to (limited) funding streams for local economic development, such as the Regional Growth Fund (RGF; a £2.4 billion pot for regeneration projects, available from 2011 to 2015). Many LEPs controlled some RGF funds designed for very small projects, but most of the RGF is administered by central government, with LEPs required to work with local firms to apply to the centre. The devolution of power to local government encapsulated by 'city deals' has also been organised in parallel with LEPs. City deals are the mechanism through which central government has sought to devolve powers to combined authorities (consortia of local authorities, typically organised on a city-regional basis). City deals have to date also focused rather too much on devolving the responsibility to deliver national policy, rather than the responsibility to decide on how best to support local economies. The most significant move towards decentralisation to date involves Greater Manchester taking control of the region's health and social care budgets. However, 'at the moment, "devo-health" is more akin to delegation than devolution' (Quilter-Pinner, 2016: 1). Furthermore, and more significantly, very few economic policy powers being devolved to Northern local authorities constitute a meaningful opportunity to develop industrial policy at the local level. Many local authorities are likely to end up with some new powers over transport, although generally not powers to decide on major infrastructure projects. Some planning powers and housing budgets will be devolved, alongside some aspects of central government's training, skills, employment support and business support services - with all recent and future spending cuts devolved too. Limited central government budgets for direct investment in productive activity will remain exactly where they are. And too often, delivery powers require local authorities to outsource the actual administration of, for example, employment support programmes, relying on many of the same firms hitherto contracted by central government (Berry, 2016a: 42-43). It is revealing that the Treasury has been almost solely responsible for the devolution agenda within central government; this has led to a dealmaking process typical of Treasury statecraft (see the chapter by Lee in this volume for a longer discussion of the Treasury). Tellingly, the announcement of new or updated city deals is often accompanied by announcements around new investment in infrastructure or regeneration - yet these initiatives typically remain under central government's control.

It would be interesting at this point to note the contribution of veteran Conservative cabinet minister (and rival to Margaret Thatcher), Michael Heseltine, to coalition thinking around local growth and industrial policy. Heseltine's 2012 report No Stone Unturned in Pursuit of Growth, commissioned - but not necessarily enthusiastically - by George Osborne, offered a fairly lavish vision for the state in co-ordinating an economy-wide growth plan, joining up all both national and local government, and public and private sector, initiatives to improve UK productivity and competitiveness Heseltine, 2012). His key recommendation was that all public spending relevant to economic growth (he identified around $£ 50$ billion in relevant spending per year) should be devolved. More precisely, he recommended that this expenditure should be amalgamated into a single fund, enabling LEPs to apply to central government for access to these funds. As such, Heseltine offered a somewhat surreal approach, with little grounding in how central government budgets actually function, or indeed any understanding of how LEPs operate in practice. Nevertheless, while Osborne rejected the notion of devolving budgets on this scale to local government in any form, we can trace similarities in the sentiments of both men, insofar as Osborne viewed the city deal process as one in which local government could be refashioned in the image of Heseltine, with local authorities themselves becoming more LEP-like, seeking primarily to attract exogenous investment rather than playing a meaningful role in governing the local economy. 
Heseltine may support a stronger role for the state, but it is nevertheless a technocratic, depoliticised state.

Interestingly, No Stone Unturned includes very few references to manufacturing, or any particular manufacturing industry. Manufacturing may have resurfaced in the Conservative approach to localised industrial policy, but perhaps only as something that local government must itself find ways of supporting, without a substantive strategy at the national level. In the Conservative approach, cities, rather than industries or governments, are the new agents of economic history, but only insofar as cities are conceived as the ideal incubator of market dynamics. This approach is heavily influenced by the 'new urban economics' and 'new economic geography', forms of spatial economics drawing substantially upon neoclassical theory, which emphasise urban 'agglomeration' as a more perfect form of market dynamics, creating sustainable economic equilibria - and explaining disequilibrium with reference to public interventions to protect unecomonic forms or spatial organisation (Engelen et al, 2016; Martin, 2015; Martin et al, 2015; see also the chapters by Martin and Gardiner, and Gray, Dickinson and Pugalis in this volume) (These perspectives had of course influenced New Labour's approach to regional governance, and the evolution of the RDAs (Pike at el, 2016).) There is even a catapult centre devoted to 'future cities' (based in London) which, apparently, 'accelerate[s] urban ideas to market, to grow the economy and make cities better' (Future Cities Catapult, 2016).

In Heseltine's vision, the fixation on cities equates to enriching business-led LEPs. For Osborne, far more attuned to the intricacies of political power and symbolism, it equates to the establishment of so-called 'metro-mayors', directly-elected to oversee combined authorities within city-regions. The scope of powers to be allocated to metro-mayors remains far from certain - this is seemingly not a primary consideration for national policy-makers beyond chairing existing or new combined authority boards. The Northern Powerhouse therefore takes on greatest significance insofar as the North of England is deemed to be home to a handful of large cities, whose interests will be promoted by this agenda. The focus on the region's metropolitanism, rather than any other socio-economic characteristics, helps to explain the prominence of transport investment and planning rules in growth plans. When the Treasury replaced the 2011 growth plan with 'the productivity plan', following the 2015 general election, the associated document Fixing the Foundations listed 'Resurgent cities, a rebalanced economy and a thriving Northern Powerhouse' as one of the key ambitions towards delivering 'a dynamic economy', which was identified alongside 'long term investment' as one of two drivers of national productivity. It is interesting perhaps that there were no explicit references to the North in relation to the long term investment driver, and that the key ambition in relation to a dynamic economy was labour market deregulation (HM Treasury, 2015b). Despite the focus on productivity, Fixing the Foundations does not contain a single reference to manufacturing.

Despite its implicit, yet deliberate, allusion to the UK's past manufacturing glories, the Northern Powerhouse, and its partial embodiment in the city deals process, essentially represents a form of 'bottom-up horizontalism' within UK industrial policy. While the valorisation of city-led growth alludes to the possibility of vertical intervention at the local level to support local industries, in actual fact the transposition of responsibility for industrial policy to the local level probably serves to dilute even the horizontal forms of intervention traditional favoured by UK policy-makers. The Northern Powerhouse is a largely place-blind agenda in which cities are asked to improve the attractiveness of their areas to business, but not primarily to assist firms in improving their performance once situated within the their jurisdiction. The key tax change related to devolution (relevant to all local authorities) fits the notion of bottom-up horizontalism well. Amid ongoing city deal negotiations between the Treasury and local authorities in 2015 , the government announced the wholesale devolution 
of business rates (a tax on the physical footprint of private companies), alongside the phased withdrawal of central government grants to local authorities. The move (which is discussed by both Bailey, and Muldoon-Smith and Greenhalgh, at greater length in their chapters in this volume) is ostensibly designed to enable city-regions to exercise greater control over their finances, yet clearly benefits those areas with strong, existing private sector bases, which of course already tend to be more affluent than those lacking this characteristic. Moreover, while the simultaneous withdrawal of central grants inherently disincentivises local authorities from increasing business rates, just to be on the safe side, the government prohibited increases at the local level without the prior approval the private sector appointees on the relevant LEP board, and even then increases must take the form of a capped surcharge to fund a specific, local infrastructure project (HM Treasury, 2015a).

\section{The de-development of Northern England}

\section{Development and unevenness}

As intimated above, the North or the manufacturing industries located within Northern regions cannot be understood in isolation, from either the rest of the UK or the global economy. The notion of 'uneven development' has become increasingly important to critically-minded social scientists interested in the fortunes of areas like the North of England. The concept implies not simply that different areas have different levels of affluence (or are at different stages of development) but, furthermore, that the economic experience of different areas are related and in interaction with each other (Peck and Theodore, 2007). In this vein, Ron Martin (2015) challenges regional studies to adopt both a 'total national system' framework (in which scholars assess 'a nation-wide evolving pattern of combined and uneven geographical development, set in the context of that national economy's changing external linkages and interactions and its evolving internal institutional and political structures') and a 'total place' framework (assessing a 'region's or city's economy in all its multi-scalar detail, as a complex open system set within the relevant national and international networks and structures to which it relates and with which in interacts') (Hudson, 2015: 262-263). Accordingly, Martin finds little evidence that efforts to rebalance the UK economy towards the North and manufacturing are transformative of the basic structures and relationships upheld at the national level, and supported internationally, which provide for uneven development within the UK economy (2015: 264).

The links between seemingly local development projects is central to Ray Hudson and Dan Swanton's (2012) report on the fascinating case of the decline in steel production in both Teesside and Dortmund, Germany, alongside the simultaneous expansion of production in China. Somewhat remarkably, after ending production in Dortmund, German steel producer ThyssenKrupp dismantled the bulk of the relevant steelworks, and sold and shipped it to a Chinese producer for reassembly in Jiangsu Province. In contrast, the British equivalent had little resale value given the lack of investment in modernisation. While steelmaking capacity was therefore retained in the North temporarily, with the plant eventually reopened under the ownership of Indian conglomerate Tata (to service, primarily, Indian demand) paradoxically this put the UK in competition with Chinese producers, with little evidence of capacity within the UK to develop more advanced production techniques (domestic steel demand in the UK, in areas such as defence and transport infrastructure, is generally met through imports). The recent turmoil around the likely closure of the Tata plant in Teesside, due in part to price manipulation by the Chinese government (which the UK government sought to prevent European authorities challenging - signifying that the UK policy elite is probably more concerned with the country's political and economic relations with China than prosperity in 
the North) is as predictable as it is devastating for those directly affected. While Dortmund has evolved into an important urban economy within the global, post-industrial core, benefiting from high-value manufacturing activity in neighbouring cities, Teesside, largely isolated from post-industrial prosperity in some Northern cities, has become increasingly vulnerable to shifting hierarchies within global production networks.

As important as this literature (spanning regional studies and economic geography) is, it probably takes for granted too readily what it means for an economy to develop or become 'more developed'. Recognising that development is an uneven process, and that processes such as deindustrialisation create new hardships, is not quite the same as arguing that deindustrialisation may actually represent a form of 'de-development'. There remains a strong sense in UK public discourse (and within parts of the academic community) that postindustrialism represents a 'higher' stage of economic development (see Davis, 2011; Kay, 2016). Two sets of responses to this are possible. The first concerns the role, noted above, of a strong manufacturing sector in the prospects for sustainable growth, and particularly productivity improvements. Manufacturing is the motor of innovation, and acts to support and propel other sectors in an infinite number of ways (Chang, 2014; Pike et al, 2012). Of course, in theory the North need not necessarily itself house a large manufacturing sector in order to benefit from the fruits of manufacturing - and nor can we assume that, even if it were able to revive its manufacturing base, the North would necessarily capture the bulk of the benefits, or indeed create large numbers of new manufacturing jobs. However, the more salient point is that manufacturing matters to more than elite discourses tend to recognise, and that by building upon its traditional strength in manufacturing, the North will be able to more effectively control its own destiny.

A second set of related responses, best represented in the critical international political economy literature, concerns a complementary narrowing and broadening of the notion of development, enabled by distinguishing clearly between development and (capitalist) growth. Accordingly, the notion that development must take a particular economic form is eschewed, with the development concept redeployed more narrowly in terms of a development 'model' which crystallises a particular approach to securing growth (and which may be a flawed approach, or partial to the interests of some groups over others). At the same time, this literature shows that all (political) economies are constantly 'developing' in a broader sense. Development is not a process with an end-point, but rather a way describing multidimensional processes of economic change. From this perspective, what is most important to understand is whether a given polity is able to exercise meaningful control over these processes (Bishop, 2016; Payne, 2005; Payne \& Phillips, 2009). Although this perspective has to date been largely agnostic about manufacturing, and is concerned mainly with national economies (and the relationships between them) rather than local economies, its application to the North does not require too great an intellectual leap. Irrespective of the centrality of manufacturing to sustainable growth in general terms, the North's particular experience of deindustrialisation has been accompanied by a decentring of Northern regions from the UK's prevailing development model (in narrow terms), but also, relatedly, the increased vulnerability of development processes (in broad terms) within the North to exogenous forces.

\section{De-development in the Northern periphery?}

The question of whether the North is in fact de-developing may therefore offer an important framing for future research. This concept has a relatively limited genealogy in social science. It has been applied in a fairly conventional manner - with de-development understood as a reversal of upward trends in quantitative indicators of improvements in living standards and 
economic growth - to countries transitioning to liberal democracy following the collapse of the Soviet Union (Meurs \& Ranasinghe, 2013). More prominently, and more interestingly, it has been applied to the case of Palestine, following Sara Roy's work on the economy of the Gaza Strip, which showed that Gaza was de-developing despite having experienced relatively strong output growth since the 1960s, because Israeli rule 'weakens the ability of [Gaza's] economy to grow and expand by preventing it from accessing and utilizing critical inputs needed to promote internal growth beyond a specific structural level' (Roy, 1987). Eventual economic collapse in Palestine perhaps vindicates Roy's view - that this collapse was a consequence of Israel security policy, rather than any economic weakness, strengthens rather than undermines this point, assuming we accept the broader understanding of development suggested above. Foreign aid now sustains the Palestinian economy, but in a way, argues Hani Mahmoud (2014), that also reinforces de-development. The concept has even been applied recently to the UK, in a polemical book by economics journalists Larry Elliott and Dan Atkinson (2012) on what they see as the imminent absolute decline of the UK economy, compounding post-war relative decline. The loss of UK manufacturing features heavily in Elliott and Atkinson's account, although they frustratingly understand development in rather crude terms, insofar as they see the de-development process as one in which the UK will start to resemble 'a third world economy'. This is clearly an over-statement, and probably misses the real significance of what might be happening in different parts of the UK. Northern England is clearly not becoming what would be understood in conventional parlance as an under-developed economy, but it may be losing what power it has over its own fate. That this might not apply uniformly to the North is a rather mundane inevitability, but could also underline the fact that in order to achieve growth, Northern cities and/or regions must compete with each other for the favour of external entities.

Agglomeration-based dogma about the importance of cities reinforces this situation, insofar as it reduces the Northern economic space to a set of discrete urban centres (legitimising their political separation at the same as stronger transport links between Northern cities are advocated). This is of course not to suggest that the North can only develop qua the North, or that cities are economically insignificant. The first section of this chapter endorsed the view that some (post-industrial) cities are to some extent transcending national borders to form a new global economic core. The question is whether an economic strategy which privileges urban centres (including, furthermore, the North's relatively miniscule urban centres) is likely to benefit the Northern economy. This is a particularly important issue given that it is a strategy which also underpins the process of devolution to the North. Calvin Jones' (2015) response to Ron Martin's challenge to regional studies advocates a world-systems approach to studying local and regional economic development, following the approach to international relations and the global economic order developed by Immanuel Wallerstein. Wallerstein understood the global political economy in terms of core and peripheral (and semi-peripheral) nation-states, with variable levels of development across the world not simply transitory, but rather a structural product of the governance of the global order by core countries. Jones seeks to introduce this approach to the study of uneven development within countries, which he sees in parallel to, and in part a function of, global unevenness. Crucially, it is within countries that we can see more precisely how complex circuits of capital are shaped by institutions of political governance external to the economic spaces in question - Jones argues this is central to understanding the uneven spatiality of capitalist organisation (Jones, 2015; see also Engelen et al, 2016).

The lesson, perhaps, is that the North has to be understood as a peripheral part of the British economy (we can speculate that it occupies a semi-peripheral status within the global economy, despite its location within a traditional core economy), notwithstanding the possibility that some parts of the North are more peripheral than others, and that other parts 
of the UK may belong in the same category. Simply trying to replicate in the North what has (apparently) enabled London - and other Southern cities, to a lesser extent - to proper within an emerging global core of transnational cities may be a fallacious strategy. Moreover, because the cities-based strategy is a product of the same national-level governance procedures that act to sustain unevenness within the UK, it may be that the privileging of the larger Northern cities, at the expense of Northern regions as a whole, enables them to prosper as satellite cities of the transnational core, without challenging the structures that ultimately underline their subservience. As such, the North's recent successes tend to be built upon the location of regional outposts of London-centred financial and business service industries within city-centres, coupled with the coterminous expansion of retail, leisure and hospitality industries. The conflation of industrial and regional policy characterised here as bottom-up horizontalism allows for a degree of prosperity among the strongest post-industrial cities, but not for large-scale upgrades in manufacturing capacity, nor for any systematic strategy to address inequality. Moreover, while some parts of the North may be growing, this does not mean they are not stuck in the same de-development trap, because their prosperity depends on the persistence of political-economic structures within which the North is inherently subservient. The ongoing failure of the North to systematically renew its manufacturing capacity illustrates well that the North lacks the authority to adopt a development model which builds upon its own endogenous strength in manufacturing - reinforced by a focus of regeneration initiatives on city centres at the expense of the range of geographies in which contemporary, high-value production might actually be located.

Even the apparent exceptions to this trend (no historical process is unidirectional) are quite revealing. Sheffield city-region, for instance, has been successful in retaining and reviving some high-value dimensions of engineering related to steel production, albeit with only a limited role for native (or even British) enterprises. Similarly, the discovery of 'miracle material' graphene in Manchester has not led to the establishment of new graphene-based industries in the local economy on any significant scale, in part due to the UK's broken highvalue manufacturing supply chains (Institute of Mechanical Engineers, 2013; Froud et al, 2011) - the graphene experience is at the time of writing subject to an inquiry by the science and technology select committee in the UK parliament. Furthermore, the relocation of old manufacturing industries, such as car manufacturing, to parts of the North East where it had not traditionally been strong is consistently lauded as a rebalancing success story, yet it is paradoxically only possible because deindustrialisation in the North East has made its economy more amenable to lower-skill assembly processes. (And there are already signs that Brexit problematises this arrangement in disrupting the business model of foreign producers based in the North.) No parts of the North can be said to have been successful in developing industries connected to computers and consumer electronics. The focus of post-crisis industrial policy on supporting science and R\&D may, or may not, be the correct focus for the UK economy as a whole, but even if this were the case, we can conclude that few parts of the North are in a position to take advantage of the new resources associated with this strategy (an issue further explored in Kieron Flanagan and James Wilsdon's contribution to this volume).

A 2016 report by think-tank Centre for Cities, comparing UK cities with European counterparts across a wide range of economic indicators, underlines the problems facing the cities of the North, as they have fallen significantly below the European average in terms of productivity, in a domestic economy more dominated by its capital city than any comparable country. The report implicitly underlines the peripheral nature of the North in international terms. Interestingly, the report also notes that successful German cities appear to be accounted for not by any particular industrial composition, but rather the co-location of cities with varying industrial strengths - including several medium-sized cities where output is 
dominated by manufacturing - within the same administrative region. The intellectual barriers to addressing the North's developmental dilemmas are evident, however, in the fact that the report's conclusions appear to ignore its own evidence. The report simply (and glibly) instead presses for the UK's underperforming cities to simply focus on attracting foreign investment into knowledge-based industries, and invest in transport links to 'better link jobs in city centres... to residential areas in suburbs and hinterlands' (Bessis, 2016: 2324). Even among the most vociferous advocates and students of local economic development, concerns that the North's development cannot simply replicate London and other Southern cities, and indeed that the North's developmental interests might conflict with the wider UK developmental model, are thoroughly marginalised.

Too often, such analysis presents cities, domestically and internationally, as either in competition with each other, or at the very least relatively isolated from each other economically. In practice, and quite obviously, city economies are highly integrated across transnational networks. As noted above, withdrawal from the EU is likely to make a manufacturing revival in the North more difficult, if not impossible. One of the few prominent academic economists who supported the leave campaign, Patrick Minford, argued in The Sun that Brexit would 'eliminate' manufacturing in the UK over the long term. He added, however, that 'this should not scare us... It is time for Britain to focus on our services and design skills, to start producing more of what we're good at' (Minford, 2016).

Nevertheless, the North voted decisively to leave in the referendum of 23 June 2016 (by 56 to 44 per cent, compared to the national result of 52 to 48 per cent). There is insufficient space here to explore why Northerners voted the way they did, and we of course cannot be certain what the very long term implications for manufacturing will be, not least because the remaining EU continues to struggle with several existential challenges. Nevertheless, it is possible to speculate that the North's support for Brexit is related to its de-development dilemma. Encased in a development model in which it is inherently subservient, and becoming increasingly stratified, many Northerners took the opportunity to register their opposition to the UK status quo, even though the implications are highly likely to cause further hardship in the North, and undermine the case for a more vertical, place-based industrial policy. (This is not to discount the influence of anti-immigration sentiment within the North - but we should not assume that this sentiment can be satisfactorily disentangled from views about the UK's economic order.)

\section{Conclusion}

The Northern Powerhouse agenda epitomises many of the challenges facing Northern England, summarised here with reference to three very dangerous Ds: deindustrialisation, devolution and de-development. The chapter's most provocative suggestion is of course that the North may be de-developing or, more precisely, stuck in a de-development trap. Yet we need not accept the efficacy of this term in full in order to recognise the bevy of development dilemmas it seeks to crystallise conceptually. All economies are of course always 'developing', that is, experiencing overlapping, multi-dimensional and contradictory processes of development. The problem, firstly, is that development in the North is largely governed under the rubric of a UK development model within which the interests of Northern regions are marginal. Secondly, the North is seemingly unable to establish an endogenous approach to achieving prosperity without further entrenching its subservience to this Londoncentred model and/or acquiescing to the deepening of inequalities within the North. The North may arguably have been more central in the past to the UK development model, and indeed part of the global economic core, but it is now firmly peripheral within the UK 
economy, and semi-peripheral, at best, in a global economic order within which London and its hinterland is the only British representative in the core.

The ongoing stutters of UK manufacturing illustrate the North's status well. A substantive revival of manufacturing in the North would empower the North, but given the longstanding indifference to manufacturing among the UK policy elite, the North would require more power to shape the UK economy in order to bring such a revival about. There should be no suggestion that a manufacturing revival would directly create a large number of new jobs in the North, given technological change within the sector, yet the fact that the productivity/jobs trade-off barely registers within public discourses around manufacturing demonstrates the extent of elite indifference to the North's economic prospects. It is not necessary to adjudicate here on whether the coalition and Conservative governments have genuinely sought to revive UK manufacturing, as the discourse around rebalancing and the Northern Powerhouse would suggest, since the financial crisis. The more salient point is that, even if this were the case, it was always very unlikely to have been achieved without seriously challenging the UK's industrial policy traditions. There are no firm reasons to believe that the May government intends to initiate this challenge, despite rediscovering the coalition's early rhetoric around industrial strategy. The notion that the North may become a 'powerhouse' of course explicitly invokes the North's historical prowess in manufacturing, but in a rather infantilising way. A sustainable manufacturing revival requires a holistic approach to economic development (and its political foundations) in places such as Northern England; simply reducing the (prospective) Northern economy to its industrial past will paradoxically inhibit the restoration of this supposedly glorious past. As it stands, the process of devolution to English city-regions - the main policy dimension of the Northern Powerhouse agenda reinforces rather than challenges the UK's industrial policy orientation, offering little more than 'bottom-up horizontalism'. Devolution is an attempt by national politicians to address evident post-crisis concerns around place, identity and local control among the electorate, yet in dividing places like the North politically into city-regions, arguably the process will serve to reduce the control that Northern citizens exercise over their local economies (Berry, 2016b).

However, there are some grounds for optimism for the North. While the Northern Powerhouse and plans for devolution might have been devised as a way to modify rather than transform the UK's pre-crisis development model, the fact that associated discourses explicitly recognise, albeit partially, the value of the North and the manufacturing sector to the UK economy may over time prove to be a significant political opening. Clearly, the UK economy, even if it is technically recovering, is struggling to resume the path of stable growth. And crucially, while Brexit will in all likelihood prove to be a self-inflicted wound for the North, not least due to the negative implications for manufacturing industries, London's finance-led economy may also be significantly impeded by the UK's withdrawal from the EU. It is not inconceivable that a more significant rupture in the UK's pre-crisis economic order will occur, enabling an enhanced role for the North in national prosperity. At the moment, however, civic leaders in the North generally remain wedded to George Osborne's vision for local growth, while national leaders of the Labour Party and the trade unions - organisations through which the North is normally represented in national politics appear not to be focused on the North's specific development dilemmas. The fact that these two groups of leaders have become effectively estranged in recent years may help to explain the inadequacies of each group's strategies for Northern development. That said, the establishment of metro-mayors may ironically provide a platform for both reconciliation and radicalism in Northern politics - as long as the new mayors' agenda involves the denunciation of the city-based vision for economic development to which they will owe their positions. 


\section{References}

Bailey, David and Driffield, Nigel (2007). 'Industrial strategy, FDI and employment: still missing a strategy', Journal of Industry, Competition and Trade, 7(3), 189-211.

Bailey, David, Hildreth, Paul and De Propris, Lisa. (2015). 'Mind the gap! What might a place-based industrial and regional policy look like?', in David Bailey, Keith Cowling and Philip R. Tomlinson (eds) New Perspectives on Industrial Policy for a Modern Britain. Oxford: Oxford University Press, 263-286.

Berry, Craig (2015a). 'The final nail in the coffin? Crisis, manufacturing decline, and why it matters', in Jeremy Green, Colin Hay and Peter Taylor-Gooby (eds) The British Growth Crisis: The Search for a New Model. Basingstoke: Palgrave, 174-197.

Berry, Craig (2015b). 'Towards a new industrial imaginary for Britain', in Johnna Montgomerie (ed.), Forging Economic Discovery in $21^{\text {st }}$ Century Britain. London: Goldsmiths PERC, 39-41.

Berry, Craig (2016a). Austerity Politics and UK Economic Policy. Basingstoke: Palgrave.

Berry, Craig (2016b). 'The resurrected right and disoriented left: growth model failure and the nascent politics of a transformative narrative', SPERI Paper \#27. Available from: http://speri.dept.shef.ac.uk/wp-content/uploads/2016/02/SPERI-Paper-27-The-

Resurrected-Right-and-Disoriented-Left.pdf [accessed 23 September 2016].

Berry, Craig (2017) 'Industrial policy change in Britain's post-crisis economy: policy innovation in an incomplete institutional and ideational environment', British Journal of Politics and International Relations, forthcoming.

Berry, Craig and Hay, Colin (2016). 'The Great British "rebalancing" act: the construction and implementation of an economic imperative for exceptional times', British Journal of Politics and International Relations, 18(1), 3-25.

Berry, Craig, Lavery, Scott, Hunt, Tom and Kirkland, Christopher (2016). UK Regions, the European Union and manufacturing exports. Available from: http://speri.dept.shef.ac.uk/wp-content/uploads/2016/05/Brief23-UK-regions-the-EU-andmanufacturing-exports.pdf [accessed 12 August 2016].

Bessis, Hugo (2016). Competing With the Continent: How UK Cities Compare With Their European Counterparts, Centre for Cities. Available from: http://www.centreforcities.org/wp-content/uploads/2016/09/16-09-21-Competing-withthe-continent.pdf [accessed 22 September 2016].

Bishop, Matthew (2016). 'Rethinking the political economy of development beyond "the rise of the BRICS", SPERI Paper \#30. Available from: http://speri.dept.shef.ac.uk/wpcontent/uploads/2016/07/Beyond-the-Rise-of-the-BRICS.pdf [accessed 18 September 2016].

Bowman, Andrew, Froud, Julie, Johal, Sukhdev, Law, John and Leaver, Adam (2014). The End of the Experiment: From Competition to the Foundational Economy. Manchester: Manchester University Press.

Bullen, Elisa (2015). Indices of Deprivation 2015, Manchester City Council Briefing Note. Available from: http://www.manchester.gov.uk/downloads/download/414/research_and_intelligence_popu lation_publications_deprivation [accessed 11 August 2016].

Buigues, Pierre-André and \& Sekkat, Khalid (2009). Industrial Policy in Europe, Japan and the United States: Amounts, Mechanisms and Effectiveness. Basingstoke: Palgrave Macmillan. 
Cable, Vince (2011). 'Speech on industrial strategy', speech delivered on 26 October. Available from: https://www.gov.uk/government/speeches/business-secretary-speech-onindustrial-strategy-at-policy-exchange [accessed 3 May 2016].

Cable, Vince (2012). 'Vince Cable's letter on industrial policy in full', The Telegraph, 6 March. Available from: http://www.telegraph.co.uk/news/politics/9126795/Vince-Cablesletter-on-industrial-policy-in-full.html [accessed 3 May 2016].

Cameron, David (2010). 'Transforming the British economy: coalition strategy for economic growth', speech delivered on 28 May. Available from:

https://www.gov.uk/government/speeches/transforming-the-british-economy-coalitionstrategy-for-economic-growth [accessed 3 May 2016].

Chakrabortty, Aditya (2016). 'The case against Osborne is clear. But Corbyn has to provide an alternative', The Guardian, 15 March. Available from: https://www.theguardian.com/commentisfree/2016/mar/15/budget-2016-jeremy-corbynalternative-osborne [accessed 22 August 2016].

Chang, Ha-Joon (2014). Economics: The User's Guide. London: Penguin.

Christensen, John, Shaxson, Nick and Wigan, Duncan (2016). The finance curse: Britain and the world economy', 18(1), 255-269.

Coates, David (2015). 'Industrial policy: international experiences', in David Bailey, Keith Cowling and Philip R. Tomlinson (eds) New Perspectives on Industrial Policy for a Modern Britain. Oxford: Oxford University Press, 41-59.

Davis, Evan (2012). Made in Britain: Why Our Economy is More Successful Than You Think. London: Abacus.

Dicken, Peter (2002). 'Global Manchester: from globaliser to globalised', in Jamie Peck and Kevin Ward (eds) City of Revolution: Restructuring Manchester. Manchester: Manchester University Press, 1-33.

Dorling, Danny (2010). 'Persistent North-South divides', in Neil M. Coe \& Andrew Jones (eds), The Economic Geography of the UK. London: SAGE, 12-28.

Elledge, John (2016). 'Have southern English cities grown faster than northern ones? The answer may surprise you', CityMetric, 11 August. Available from: http://www.citymetric.com/politics/have-southern-english-cities-grown-faster-northernones-answer-may-surprise-you-2340 [accessed 11 August 2016]

Elliott, Larry and Atkinson, Dan (2012). Why Britain Will Have a Third World Economy By 2014. Basingstoke: Palgrave.

Engelen, Ewald, Froud, Julie, Johal, Sukhdev, Salento, Angelo and Williams, Karel (2016). 'How cities work: a policy agenda for the grounded city', CRESC Working Paper No. 141. Available from: http://www.cresc.ac.uk/medialibrary/workingpapers/wp141.pdf [accessed 1 September 2016].

English, Richard and Kenny, Michael (2000). 'Decline or declinism?' in Richard English \& Michael Kenny (eds) Rethinking British Decline. Basingstoke: Macmillan, 279-99.

Froud, Julie, Johal, Sukhdev, Law, John, Leaver, Adam and Williams, Karel (2011). 'Rebalancing the economy (or buyer's remorse)', CRESC Working Paper No. 87. Available from: http://www.cresc.ac.uk/publications/rebalancing-the-economy-or-buyersremorse [accessed 28 February 2014].

Future Cities Catapult (2016). 'Who we are'. Available from: https://futurecities.catapult.org.uk/about/ [accessed 5 September 2016].

Gamble, Andrew (2000). 'Theories and explanations of British decline' in Richard English \& Michael Kenny (eds) Rethinking British Decline. Basingstoke: Macmillan, 1-22.

Giordano, Benito and Twomey, Laura (2002). 'Economic transitions: restructuring local labour markets', in Jamie Peck and Kevin Ward (eds) City of Revolution: Restructuring Manchester. Manchester: Manchester University Press, 50-75. 
Hall Peter A. and Soskice, David (2001) (eds). Varieties of Capitalism: The Institutional Foundations of Comparative Advantage. Oxford: Oxford University Press.

Haughton, Graham, Deas, Iain, Hincks, Stephen and Ward, Kevin (2016). 'Mythic Manchester: Devo Manc, the Northern Powerhouse and Rebalancing the English Economy', in Cambridge Journal of Regions, Economy and Society, forthcoming. Available from: http://cjres.oxfordjournals.org/content/early/2016/04/07/cjres.rsw004.abstract [accessed 19 September 2016].

Herd, Dean and Petterson, Terry (2002). 'Poor Manchester: old problems and new deals', in Jamie Peck and Kevin Ward (eds) City of Revolution: Restructuring Manchester. Manchester: Manchester University Press, 190-213.

Heseltine, Michael (2012) No Stone Unturned in Pursuit of Growth. Available from: https://www.gov.uk/government/uploads/system/uploads/attachment_data/file/34648/121213-no-stone-unturned-in-pursuit-of-growth.pdf [accessed 19 August 2016].

HM Government (2009). New Industry, New Jobs. Available from: http://webarchive.nationalarchives.gov.uk/20100430155636/http://www.bis.gov.uk/files/fi 1e51023.pdf [accessed 3 May 2016].

HM Government (2010). The Coalition: Our Programme for Government. London: The Stationery Office.

HM Government (2014). Industrial Strategy: Government and Industry in Partnership Progress Report. Available from:

https://www.gov.uk/government/uploads/system/uploads/attachment_data/file/306854/bis14-707-industrial-strategy-progress-report.pdf [accessed 3 May 2016].

HM Treasury and Department for Business, Innovation and Skills (2011). The Plan for Growth. Available from: https://www.gov.uk/government/uploads/system/uploads/attachment_data/file/31584/2011 budget_growth.pdf [accessed 3 May 2016].

HM Treasury (2015a). 'Chancellor unveils "devolution revolution"”, press release issued on 5 October 2015. Available from: https://www.gov.uk/government/news/chancellor-unveilsdevolution-revolution [accessed 8 November 2015].

HM Treasury (2015b). Fixing the Foundations: Creating a More Prosperous Nation. Available from: https://www.gov.uk/government/uploads/system/uploads/attachment_data/file/443898/Pro ductivity_Plan_web.pdf [accessed 19 August 2016].

Hudson, Ray (2005). Rethinking change in old industrial regions: reflecting on the experiences of North East England', Environment and Planning A, 37(4), 581-596.

Hudson, Ray (2013). 'Thatcherism and its geographical legacies: the new map of sociospatial inequality in the Divided Kingdom', The Geographical Journal, 179(4), 377-381.

Hudson, Ray and Swanton, Dan (2012). 'Global shifts in contemporary times: the changing trajectories of steel towns in China, Germany and the United Kingdom', in European Urban and Regional Studies. 19(1), 6-19.

Ingham, Geoffrey (1984). Capitalism Divided? The City and Industry in British Social Development. London: Macmillan.

Institute of Mechanical Engineers (2013). Graphene: Small Wonders, Slow Progress. Available from: http://www.imeche.org/docs/default-source/public-affairs/imechegraphene-ps.pdf?sfvrsn=0 [accessed 18 September 2016].

Jones, Calvin (2015). 'On capital, space and the world system: a response to Ron Martin', Territory, Politics, Governance. 3(3), 273-293.

Jones, Martin (2013). 'It's like déjà vu, all over again', in Michael Ward and Sally Hardy (eds) Where Next for Local Enterprise Partnerships? London: The Smith Institute, 86-95. 
Kay, John (2016). 'The economics and politics of manufacturing fetishism', John Kay's personal website, 29 August 2016. Available from: http://www.johnkay.com/2016/08/29/the-economics-and-politics-of-manufacturingfetishism/ [accessed 30 August 2016].

Mahmoud, Hani (2014). 'Foreign aid: development or “de-development”?', Open Democracy, 13 April. Available from: https://www.opendemocracy.net/arabawakening/hani-mahmoud/foreign-aid-development-or-dedevelopment [accessed 18 September 2016].

Martin, Ron (2015). 'Rebalancing the spatial economy: the challenge for regional theory', in Territory, Politics, Governance. 3(3), 236-272.

Martin, Ron, Pike, Andy, Tyler, Pete and Gardiner, Ben (2015) Spatially Rebalancing the UK Economy: The Need for a New Policy Model. London: Regional Studies Association. Available from: http://www.regionalstudies.org/uploads/documents/SRTUKE_v16_PRINT.pdf [accessed 1 September 2016].

Matthews, Derek (2007). 'The performance of British manufacturing in the post-war long boom', Business History, 49(6), 763-779.

May, Theresa (2013). 'We will win by being the party for all', speech delivered on 9 March. Available from: http://www.conservativehome.com/platform/2016/07/full-text-of-theresamays-speech-we-will-win-by-being-the-party-for-all.html [accessed 2 August 2016].

May, Theresa (2016a). 'My vision for Yorkshire's bright future', Yorkshire Post, 18 August. Available from: http://www.yorkshirepost.co.uk/news/opinion/theresa-may-my-vision-foryorkshire-s-bright-future-1-8074726 [accessed 23 August 2016].

May, Theresa (2016b) 'My plan to build a "Midlands Engine" and create more good jobs in Birmingham and beyond', The Birmingham Mail, 18 August. Available from: http://www.birminghammail.co.uk/news/midlands-news/theresa-may-plan-buildmidlands-11763399 [accessed 23 August 2016].

May, Theresa (2016c). 'We can make Britain a country that works for everyone', speech delivered on 11 July. Available from: http://www.itv.com/news/2016-07-11/what-aretheresa-mays-key-pledges-home-secretary-outlines-her-plan-for-the-future/ [accessed 2 August 2016].

Mellor, Rosemary (2002). 'Hypocritical city: cycles of urban exclusion', in Jamie Peck and Kevin Ward (eds) City of Revolution: Restructuring Manchester. Manchester: Manchester University Press, 214-235.

Meurs, Mieke and Ranasinghe, Rasika (2003). 'De-development in post-socialism: conceptual and measurement issues', in Politics and Society. 31(1), 31-53.

Minford, Patrick (2016). 'Brexit will boost our economy and cut the cost of BMWs and even brie', The Sun, 15 March. Available from:

https://www.thesun.co.uk/archives/politics/1086319/brexit-will-boost-our-economy-andcut-the-cost-of-bmws-and-even-brie/ [accessed 17 September 2016].

Office for National Statistics (2015). Regional Gross Value Added (Income Approach): December 2015). Available from:

http://www.ons.gov.uk/economy/grossvalueaddedgva/bulletins/regionalgrossvalueaddedin comeapproach/december2015\#industrial-analysis [accessed 11 August 2016].

Office for National Statistics (2016a). UK Balance of Payments: The Pink Book, 2016. Available from: https://www.ons.gov.uk/economy/nationalaccounts/balanceofpayments/bulletins/unitedkin gdombalanceofpaymentsthepinkbook/2016 [accessed 11 August 2016]. 
Office for National Statistics (2016b). UK Index of Production: June 2016. Available from: http://www.ons.gov.uk/economy/economicoutputandproductivity/output/bulletins/indexof production/june2016 [accessed 11 August 2016].

Office for National Statistics (2016c). UK Labour Market: July 2016. Available from: https://www.ons.gov.uk/employmentandlabourmarket/peopleinwork/employmentandempl oyeetypes/bulletins/uklabourmarket/july2016 [accessed 11 August 2016].

Office for National Statistics (2016d). Workforce Jobs by Region and Industry. Available from:

https://www.ons.gov.uk/employmentandlabourmarket/peopleinwork/employmentandempl oyeetypes/datasets/workforcejobsbyregionandindustryjobs05 [accessed 12 August 2016].

Osborne, George (2011). 'Budget speech', speech delivered on 23 March. Available from: http://webarchive.nationalarchives.gov.uk/20130129110402/http://www.hmtreasury.gov.uk/2011budget_speech.htm [accessed 3 May 2016].

Payne, Anthony (2005). The Global Politics of Unequal Development. Palgrave: Basingstoke. Payne, Anthony and Phillips, Nicola (2009). Development, London: Polity.

Peck, Jamie and Theodore, Nik (2007) 'Variegated capitalism', Human Geography, 31(6), 731-772.

Pike, Andy (2009). 'De-Industrialization', in Rob Kitchin and Nigel Thrifts (eds), International Encyclopaedia of Human Geography. Amsterdam: Elsevier, 51-59.

Pike, Andy, Dawley, Stuart and Tomaney, John (2012). 'How does manufacturing contribute to UK resilience? Foresight/Government Office for Science Future of Manufacturing Project Evidence Paper 28. Available from: http://www.ncl.ac.uk/curds/documents/PikeDawleyandTomaney2013HowDoesManufactu ringContributetoUKResilience-ReportforForesightProgr.pdf [accessed 11 August 2008].

Pike, Andy, Marlow, David, McCarthy, Anja, O’Brien, Peter and Tomaney, John (2015). 'Local institutions and local economic development: the Local Enterprise Partnerships in England, 2010-', Cambridge Journal of Regions, Economy and Society, 8(2), 185-204.

Pike, Andy, Coombes, Mike, O'Brien, Peter and Tomaney, John (2016a). 'Austerity states, institutional dismantling and the governance of sub-national economic development: the demise of the Regional Development Agencies in England' in Territory, Politics, Governance, forthcoming. Available from: http://eprint.ncl.ac.uk/file_store/production/226186/0FAAE69A-66B8-4042-AE097F1C83CF5F2E.pdf [accessed 2 September 2016].

Pike, Andy, Rodriguez-Pose, Andres and Tomaney, John (2016b). 'Shifting horizons in local and regional development' in Regional Studies, forthcoming. Available from: http://eprints.lse.ac.uk/67542/ [accessed 7 September 2016].

Pike, Andy and Tomaney, John (2009). 'The state and uneven development: the governance of economic development in England in the post-devolution UK'. Cambridge Journal of Regions, Economy and Society. 2(1), 13-34.

Piris, Jean-Claude (2016). If the UK Votes to Leave: Seven Alternatives to EU Membership, Centre for European Reform. Available from: http://www.cer.org.uk/sites/default/files/pb_piris_brexit_12jan16.pdf [accessed 12 August 2016].

PricewaterhouseCoopers (2009). The Future of UK Manufacturing: Reports of Its Death Are Greatly Exaggerated. Available from: https://www.pwc.co.uk/assets/pdf/ukmanufacturing-300309.pdf [accessed 28 February 2014].

Quilter-Pinner, Harry (2016). Devo-Health: What and Why? Institute for Public Policy Research. Available from: 
http://www.ippr.org/files/publications/pdf/devohealth_whatwhy_Aug\%202016_spreads.pd f?noredirect $=1$ [accessed 1 September 2016].

Roy, Sara (1987) 'The Gaza Strip: a case of economic de-development', in Journal of Palestine Studies. 17(1), 56-88.

Rowthorn, Robert and Coutts, Kenneth (2013). Deindustrialisation and the balance of payments in advanced economies, Foresight/Government Office for Science Future of Manufacturing Project Evidence Paper 31. Available from:

https://www.gov.uk/government/uploads/system/uploads/attachment_data/file/283905/ep3 1-de-industrialisation-and-balance-of-payments.pdf [accessed 11 August 2016].

Rubinstein, W.D. (1993). Capitalism, Culture and Decline in Britain, 1750-1990. London: Routledge.

Willets, D. (2012). 'Our hi-tech future', speech delivered on 4 January. Available from: https://www.gov.uk/government/speeches/our-hi-tech-future--2 [accessed 3 May 2016].

Williams, Karel, Williams, John \& Thomas, Dennis (1983). Why Are the British Bad at Manufacturing? London: Routledge \& Kegan Paul. 